\title{
Tubing facilities in the system of recreational urban territories
}

\author{
Marina Afonina ${ }^{1, *}$ and Natalya Vetrova $^{2}$ \\ ${ }^{1}$ Moscow State University of Civil Engineering, Yaroslavskoe shosse, 26, Moscow, 129337, Russia \\ ${ }^{2}$ V.I. Vernadsky Crimean Federal University, Pr. Vernadskogo 4, Simferopol, 295007, Republic of \\ Crimea
}

\begin{abstract}
The study was conducted in the field of temporary monofunctional recreational tubing facilities. Using the example of artificial structures in Moscow, city-forming and technological features as promising centers of activity of urban parks in large cities were studied. The phenomenon of continuity of modern temporary recreational facilities to the traditions of the historic "Roller slides" as a part of park spaces and independent small architectural forms was studied. The life cycle of facilities (from design and installation to dismantling) was tracked. The structural scheme of tubing facilities on the basis of rod building structures and their engineering and technological support were studied. The statistics of attendance was analyzed, and the target audience of the complexes was identified. Energy efficiency, reliability, and environmental friendliness of facilities were proved. The paper proposes a proprietary methodology for assessing the adaptability of tubing facilities to the environment. It is presented as an object matrix.
\end{abstract}

\section{Introduction}

In many countries of the world, in addition to the positive effect, modern breakthroughs in technologies for providing comfort have a number of negative aspects: the majority of adults and children lead a sedentary lifestyle and prefer to stay at home in front of TV screens and computers, and even walking, they have their eyes glued on the screens of gadgets. But a sedentary lifestyle adversely affecting the health of the entire population of the planet and can be overcome only through adherence to active recreation and recreational sports in specially organized city zones.

It should be noted that at present, an active lifestyle and sports activities affect all nations. Therefore, the construction of recreational, tourist, resort and sports complexes is studied comprehensively and everywhere. At the same time, the development of new forms of recreation initiates new research and, as a result, heterogeneous facilities and sociocultural spaces appear for traditional, street, ethnic sports and innovative types of recreational activities, which are presented in a classical form, in a virtual form, promising (in the form of mental maps), taking into account local, gender and age characteristics [1$11]$.

\footnotetext{
* Corresponding author: marinamgsu@yandex.ru
} 
Research into the development of public spaces is considered by experts from the angle of their specialty. Therefore, the development of urban areas, taking into account their individual properties, is followed by adaptation for placement in the urbanized environment of permanent or temporary recreation facilities with a large number of visitors of all age groups affects important elements of urban planning, architecture, transport, engineering issues, etc. [12-18].

Providing urban residents with affordable, useful and traditionally favorite social infrastructure is one of the tasks of sustainable development of territories. To meet the needs of different groups of the population, parks, public and green areas are used as places for active recreation, specialized activities, sports and recreational activities, and entertainment.

Foreign publications on the topic of winter complexes relate to the management of health centers and specialized resorts, their rating, the organization of sports and tourism business, technical support, the influence of natural and climatic conditions on the functioning of winter parks, resource saving, etc. Hillsdon M., Panter J., Foster C.BaronYelles, N., \& Clavé, S.A. [13], Prins, R.G., Mohnen, S.M., van Lenthe, F.J., Brug, J. \& Oenema [5], and other scientists and designers work in this area.

Russian and foreign authors comprehensively substantiate the need for the motor activity of children, adolescents, and adults. A systematic and deep approach to the study of issues of recreational and resort systems can be considered sufficiently studied. However, despite the elaboration of the theory of recreation at the level of territorial systems and their architectural and planning decisions, studies on the creation and operation of temporary recreational complexes with a narrowly specialized focus in modern scientific literature need to be updated.

The goal of the study was to concretize the modern approaches to the construction of monofunctional tubing facilities as architecturally attractive, economically and environmentally efficient, socially demanded facilities that can be part of urban parks and public territories.

To achieve this goal, the following tasks were solved:

- a historical and international review of the literature in the field of providing various groups of the population with objects of physical activity was made;

- monitoring of recreational tubing facilities was made (including objects of Moscow);

- the life cycle, design and technological features of tubing facilities were studied;

- the material was generalized, and the approaches to the creation of new recreational facilities were specified, taking into account the territory and the demands of the population.

\section{Materials and Methods}

Considering the modern approaches to the development of public territories from the position of organizing space for active recreation, we consider it necessary to take into account Russia's historical experience in the construction of seasonal facilities, including for the winter outdoor activities - "Roller slides".

The task of creating of the traditional roller slides in Russia at the new stage and with the new quality gradually began to be realized. This is facilitated by the climatic conditions of the territory, the use of the usual and new inventory available to all segments of the population. Most of the historical structures for winter entertainment, because of their specificity, have sunk into oblivion. However, few have gone down in history as examples of the skill of their creators, and they are still perfect examples for study. Popular entertainment is reflected in the works of artists, and this makes it possible to restore the 
overall picture (Fig. 1 A, B) and imagine the riding of our ancestors with a sufficient degree of authenticity.

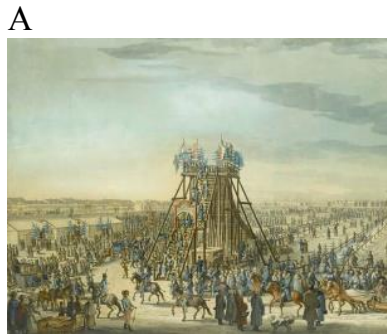

\section{B}

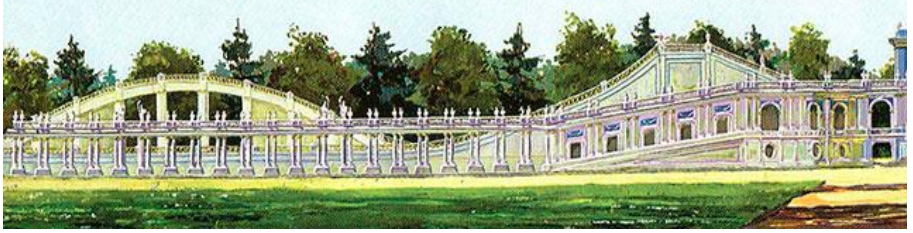

Fig. 1. Complicated historic roller slides, St. Petersburg, Russia, XVII century, where:A - Two-sided slide, 1788, Artist Benjamin Patersen (1748-1815) [19], B - Roller slide (Katalnaya gorka) in Oranienbaum, 1768, Architect A. Rinaldi, Reconstruction V. Gavrilov [20].

For a long time, sleds were not only transport, luxury and fun, but also the main attribute of riding. Modern forms of recreational facilities for traditional motor activity are characterized by the change of the usual sleds with runners for riding from the mountains to polymeric inflatable sledge-tube. In colloquial speech, this safe and fun entertainment for adults and children is called - riding on "biscuits", "bagels", "donuts", and "toboggans".

Different surfaces are used for riding: natural slopes (planar objects), special structures (temporary "transforming facilities" - linear structures), which are especially attractive as part of amusement parks, recreation areas and in areas with existing urban development. However, the experience of creating winter tubing structures and tracks as part of the complexes of the cities of Moscow, Moscow region, St. Petersburg, Samara, Gorokhovets, Izhevsk, Novosibirsk, etc., through which comprehensive monitoring has been conducted (Table 1) [21-24], has already been gained.

Facilities for riding can be natural surfaces, artificial slopes, permanent and temporary structures equipped in accordance with the requirements for the operation of amusements (lighting) with lifts and even snow substitute surfaces. The need to build special transforming facilities that can be easily adapted to any difficult conditions of large cities has become possible.

Modern temporary winter constructions in the form of slopes and trails turned from small architectural forms of local purpose into social significant objects. Favorite objects quickly became popular and semantic centers of city parks, the dominant of park compositions, which contribute to the renewal and revitalization of any location point. These facilities reach significant scale, become centers of attraction and promotion of healthy lifestyles, which allows, with minimum construction time, labor and financial costs, raising the level of favorableness (comfort) of the environment [21].

Table 1. Objects of monitoring recreational facilities (Russian tubing parks) [25-28].

\begin{tabular}{|c|l|l|l|l|}
\hline N & \multicolumn{1}{|c|}{$\begin{array}{c}\text { Complex name, } \\
\text { location }\end{array}$} & \multicolumn{1}{|c|}{$\begin{array}{c}\text { Territory status of } \\
\text { tubing facility }\end{array}$} & $\begin{array}{c}\text { Type of construction, } \\
\text { structure }\end{array}$ & $\begin{array}{l}\text { Characteristics, } \\
\text { mode of use: }\end{array}$ \\
\hline I. & $\begin{array}{l}\text { "Vsepogorka" } \\
\text { ("The Gorka") } \\
\text { Sokolniki Park, } \\
\text { Moscow }\end{array}$ & $\begin{array}{l}\text { Specially protected } \\
\text { natural area of regional } \\
\text { significance "Sokolniki } \\
\text { Natural History Park" }\end{array}$ & $\begin{array}{l}\text { Artificial construction } \\
\text { (rod building systems) } \\
\text { (linear object) }\end{array}$ & $\begin{array}{l}\text { Seasonal: } \\
2011-2017 . \\
\text { All-season: } \\
\text { from the } \\
\text { season } \\
2017 / 2018\end{array}$ \\
\hline 2. & $\begin{array}{l}\text { "Rocket" } \\
\text { All-Russian } \\
\text { Exhibition Center } \\
\text { (VDNH) }\end{array}$ & $\begin{array}{l}\text { All-Russian Exhibition } \\
\text { Center, has the status of } \\
\text { place of interest }\end{array}$ & $\begin{array}{l}\text { Artificial construction } \\
\text { (core building } \\
\text { systems)* (linear } \\
\text { object) }\end{array}$ & Seasonal \\
\hline
\end{tabular}




\begin{tabular}{|c|c|c|c|c|}
\hline & Moscow & & & \\
\hline 3 & $\begin{array}{l}\text { Tubing track in the } \\
\text { park of the 50th } \\
\text { anniversary } \\
\text { October, } \\
\text { Moscow }\end{array}$ & $\begin{array}{l}\text { Moscow City Forest } \\
\text { Park }\end{array}$ & $\begin{array}{l}\text { Natural slope }+ \text { linear } \\
\text { artificial structure } \\
\text { (wooden structures) } \\
\text { (linear object) }\end{array}$ & All-season \\
\hline 4 & $\begin{array}{l}\text { "Freestyle" } \\
\text { Tubing Park } \\
\text { Moscow region, } \\
\text { Dzerzhinsky }\end{array}$ & $\begin{array}{l}\text { Recreational area - } \\
\text { extreme city park }\end{array}$ & $\begin{array}{l}\text { Slope as a part of an } \\
\text { artificial soil structure } \\
\text { (areal object) }\end{array}$ & Seasonal \\
\hline 5 & $\begin{array}{l}\text { "Sorochany" Tubing } \\
\text { Park } \\
\text { Moscow region, } \\
\text { Dmitrov district }\end{array}$ & $\begin{array}{l}\text { Recreational area - ski } \\
\text { complex }\end{array}$ & $\begin{array}{l}\text { Slope as a part of an } \\
\text { artificial soil structure } \\
\text { (areal object) }\end{array}$ & Seasonal \\
\hline 6 & $\begin{array}{l}\text { Tubing track, } \\
\text { Zagorodny Park, } \\
\text { Samara }\end{array}$ & $\begin{array}{l}\text { Zagorodny Park, } \\
\text { Samara }\end{array}$ & $\begin{array}{lr}\begin{array}{l}\text { Natural } \\
\text { building } \\
\text { (wooden) }\end{array} & \text { relief } \\
\text { object) } & \text { structures } \\
\text { objinear }\end{array}$ & All-season \\
\hline 7 & $\begin{array}{l}\text { Tubing facility in } \\
\text { the park of the } 30 \text { th } \\
\text { anniversary } \\
\text { Victory, } \\
\text { Samara }\end{array}$ & $\begin{array}{l}\text { City park of the 30th } \\
\text { anniversary of Victory, } \\
\text { Samara }\end{array}$ & $\begin{array}{l}\text { Natural relief (areal } \\
\text { object) }\end{array}$ & Seasonal \\
\hline 8 & $\begin{array}{l}\text { Tubing park as part } \\
\text { of "Puzhalova } \\
\text { mountain" ski } \\
\text { complex, } \\
\text { Gorokhovets }\end{array}$ & $\begin{array}{l}\text { Recreational area - ski } \\
\text { complex }\end{array}$ & $\begin{array}{l}\text { Natural relief (areal } \\
\text { object) }\end{array}$ & $\begin{array}{l}\text { Seasonal } \\
\text { All-season (in } \\
\text { part of the } \\
\text { territory) }\end{array}$ \\
\hline
\end{tabular}

* - modular scaffolding COMBI metric.

Using traditions and introducing innovations, it is possible to create specialized recreational objects in multivariate space and planning, constructive and technological solutions for which are used:

- natural and artificial horizontal or inclined surfaces (relief);

- wooden structures;

- rod building systems;

- products made of ice (freezing water) (not considered in this work);

- a combination of options, complemented by small architectural forms.

The most large-scale Russian tubing facilities are two metropolitan tubing facilities: "Rocket" at the All-Russia Exhibition Center-VDNH (2017-2018) and "Vseopogorka" (formerly "The Gorka") in the Sokolniki Park (2011/2019).

We will conduct a comprehensive analysis of constructive decisions, "life cycle" and social indicators of the most significant recreational facilities.

\section{1 "Rocket" tubing slide}

The territory of the All-Russia Exhibition Center-VDNH has been used for several years to accommodate temporary tubing slides from scaffolding. But the "Rocket" of the 2017/2018 winter season, which harmoniously fit into the overall planning concept of Industry Square, became the biggest slide. The place was chosen as the most ceremonial - on the main axis of the park (Fig. 2A), where at the beginning of December 2017, the largest and most 
complicated roller tubing slide was built - a slide that fit into the general structure of the recreation area.

A

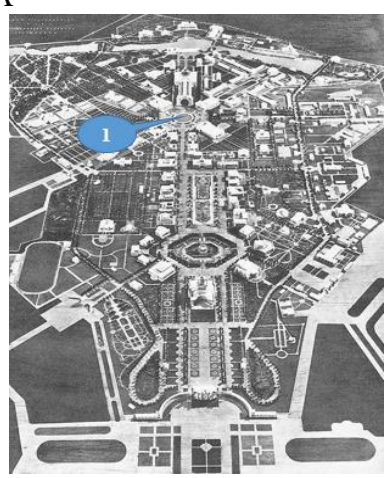

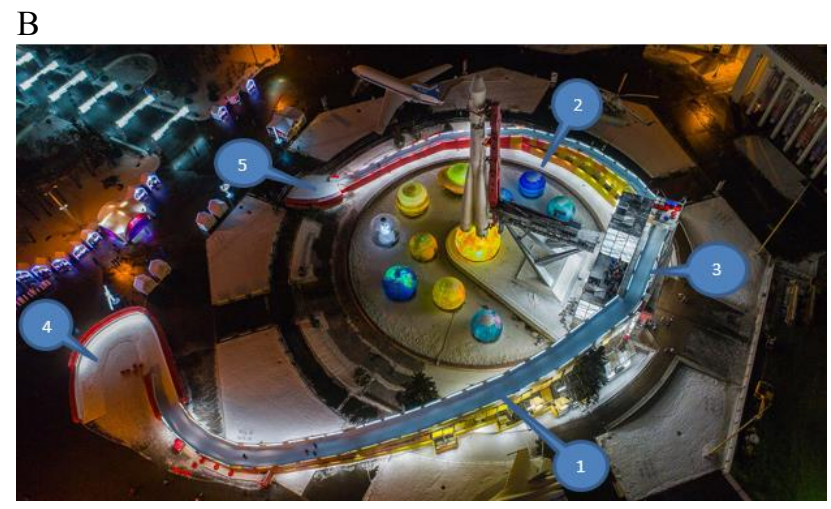

Fig. 2. "Rocket" tubing slide, Moscow, winter 2017-2018 A - On the park plan [29]. B - Top view [30].

The structure was located around the fountain bowl at the Vostok launch vehicle model and consisted of installing 9 luminous planets of the Solar System (from $2.5 \mathrm{~m}$ to $10 \mathrm{~m}$ in diameter) with a space rocket in the center of the composition (Fig. 2B). The structure created from two curvilinear slopes ("Big" and "Small") of $20 \mathrm{~m}$ and $12 \mathrm{~m}$ high, respectively, $180 \mathrm{~m}$ and $120 \mathrm{~m}$ long, and the central zone with separate launch pads at different levels pleased the guests of the exhibition center (Fig. 3A). The structure was decorated with a transparent polymeric material, which created the effect of a full-bodied serious structure, light and bulky (Fig. 3B).

A

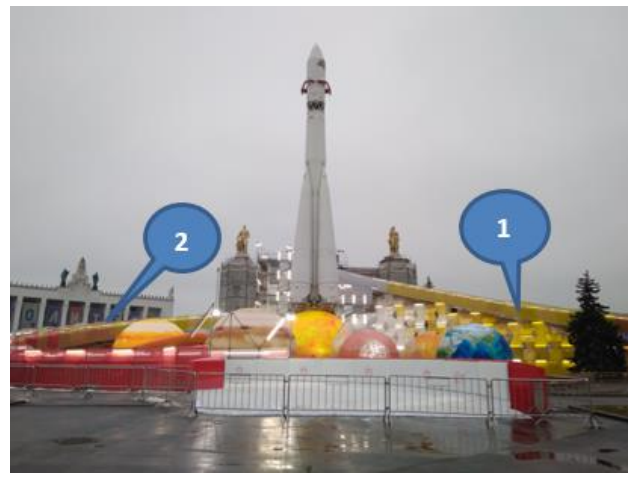

B

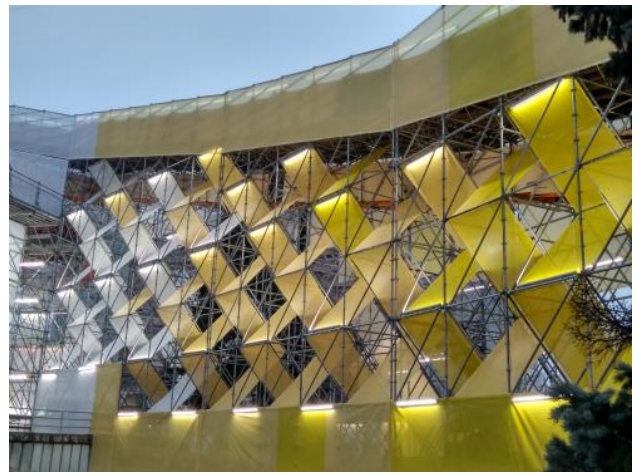

Fig. 3. "Rocket" tubing slide A - Facade. B - Fragment of the decorated facade (photo by author 02.2018).

The launch sites are located at different levels (a large slope - $20 \mathrm{~m}$, a small one - $12 \mathrm{~m}$ ). Estimated maximum number of visitors - up to 100 people. The descent time for a long slope is about 20 seconds, and short $-15 \mathrm{sec}$.

Design features

Temporary recreational facility was assembled from high-tech modern building systems COMBI metric, which are widely used in the construction of scenes, stands, canopies, pass overs, as well as temporary sports facilities for summer and winter competitions. Modular wedge scaffoldings ensure optimal costs and minimal installation time, and, most importantly, convenient and reliable connection thanks to the wedge locking principle. The 
decisive advantage of modular scaffolding is, in addition to the formation of free corners and nodes, the individual choice of the length and width of the elements and the height of the overlap. This is due to the modularity of steel screw jacks, racks, crossbars, diagonals, flooring, bakelite plywood and fasteners are used as additional materials. However, during the construction of sports and recreational facilities from standard elements, the structure becomes unique, while maintaining the linear shape, elevation differences - artificial "hills" are created due to the top cover of their sheet materials, on which snow or snow substitute cover is subsequently laid.

The advantages of the system are high speed of erection and dismantling, reusable elements, thus reducing the cost of all types of resources. The use of scaffolding saves materials, makes it possible to experiment with forms and allows the use of expensive urban areas for carrying out significant sports events and the creation of temporary recreational facilities. Thus, it becomes possible to adapt to virtually any form of structure, in our case, two curved channels, and this possibility has been implemented in practice. The experience of building temporary structures from modular building elements creates objective prerequisites for the development of a high-tech building process. On the construction of which were employed: on the installation work - 20 people, decorators - 10 20 in different periods (Table 2).

Table 2. Characteristics of the "Rocket" tubing slides at VDNH in 2017-2018.

\begin{tabular}{|c|c|c|}
\hline № & Parameters & Indicators \\
\hline 1 & Overall dimensions, $\mathrm{L} \times \mathrm{H}, \mathrm{m}$ & $180 \times 20$ \\
\hline 2 & Working surfaces & 2 tracks (in different directions) \\
\hline 3 & Start of construction & December 2017 \\
\hline 4 & Duration of construction & 4 weeks \\
\hline 5 & Stages of construction & $\begin{array}{l}\text { Installation }-1-2 \mathrm{~d} \text { weeks; } \\
\text { Laying the coating and decorating designs }-3-4 \text { th } \\
\text { weeks }\end{array}$ \\
\hline 6 & Operation period & $\begin{array}{l}58 \text { days (from } 23.12 .2017 \text { to } 18.02 .2018 \text { ) } \\
\text { from } 10.01 \text { (Tuesday - Friday from 11:00 to } 16: 00 \text {, } \\
\text { riding is free) }\end{array}$ \\
\hline 7 & Dismantling & 4 days \\
\hline 8 & Type of construction & $\begin{array}{l}\text { Collapsible metal system (MJ-Gerüst } \mathrm{GmbH} \text {, } \\
\text { GERMANY, DlBt, Berlin). } \\
\text { Frame - modular wedge scaffolding COMBI metric } \\
\text { (MJ-Gerüst). Additional elements - bolts, } \\
\text { diagonals, jacks. }\end{array}$ \\
\hline 9 & $\begin{array}{l}\text { Snow substitute coating } \\
\text { Snow plast } 365 \text { Russia } \mathrm{m}^{2}\end{array}$ & 1100 \\
\hline 10 & $\begin{array}{l}\text { Capacity (weekdays / weekends } \\
\text { and holidays) people. }\end{array}$ & up to $3000 /$ up to 7000 (depending on the weather) \\
\hline 11 & $\begin{array}{l}\text { One-time number of visitors } \\
\text { (estimated) / total number of } \\
\text { visitors per season (actual) }\end{array}$ & 100 people/more than 150 thousand people \\
\hline 12 & Actual time of descent & $\begin{array}{l}\text { from the "Big" - about } 20 \text { seconds, from the } \\
\text { "Small"- } 15 \text { seconds. }\end{array}$ \\
\hline
\end{tabular}

Spatial hinge-rod systems (spatial trusses) used in construction are characterized by a large number of elements and nodes, for which it is customary to use the finite element method in calculations. Software products with the possibility of geometrically non-linear calculations are used in the calculation. However, the programs do not always give reliable results, especially near critical points.

The calculation takes into account the following combinations of loads:

- own weight (including the weight of the channel, flooring); 
- own weight + load from visitors;

- own weight of the structure + wind load (amusement rides do not work at wind speeds of more than $15 \mathrm{~m} / \mathrm{s}$ );

- own weight of the structure + load from a moving object, taking into account the dynamic mass of visitors.

The calculations took into account the effects of the tubs in both snow and snowless weather. The shape of the tracks was created taking into account the curved trajectory of the tube movement. During the field study, it was found that in snowy weather, the tube moves more slowly, since the snow cover does not help, but even prevents a rapid ride. In heavy snow, the track was cleared of snow, which increased the speed of movement and the joy of riding.

A

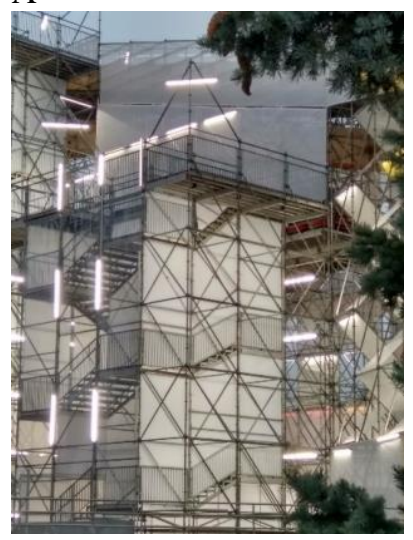

B

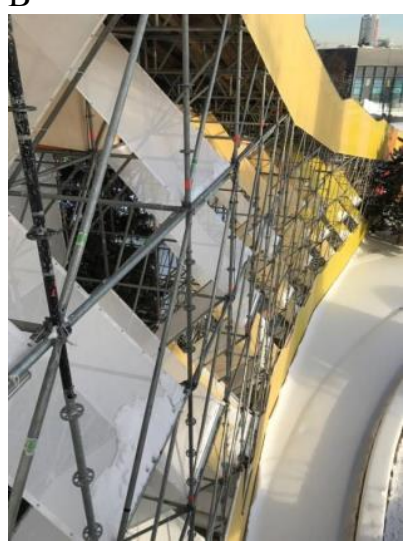

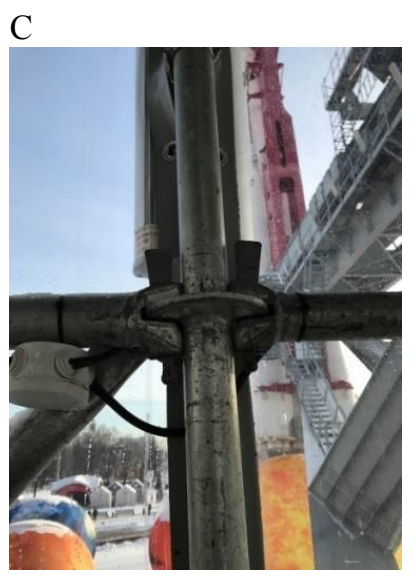

Fig. 4. "Rocket" tubing slide, VDNH in 2017-2018 (photo by author 01.2018), where: A- Ladder structure. B - Fragment of the "Big" slope. C - Fastening node.

Calculations of structural elements are carried out on the basis of the provisions of GOST 27751 "Reliability of building structures", GOST R 52170 "Safety of mechanized amusement rides", as well as the requirements of SP 20.13330 (SNiP 2.01.07-85*) "Loads and Impacts", SP 16.13330.2011 ( SNiP II-23-81*) ("Steel structures"). All calculations are carried out using special programs. The difficulty is the construction of the design $3 \mathrm{D}$ model. The calculation is carried out using the SCAD and Lira programs [31].

\subsection{Technological features}

For the convenience of visitors, on the outer side of the slopes, special rope tows with plywood flooring were created for tubes (Fig.5A, B). Those who wanted to ride climbed the stairs to the upper or lower platforms. There were tubes (Fig. 5C) on which they slid along the channel. 
A

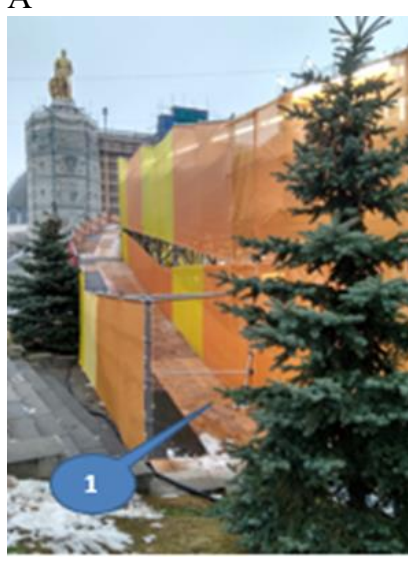

B

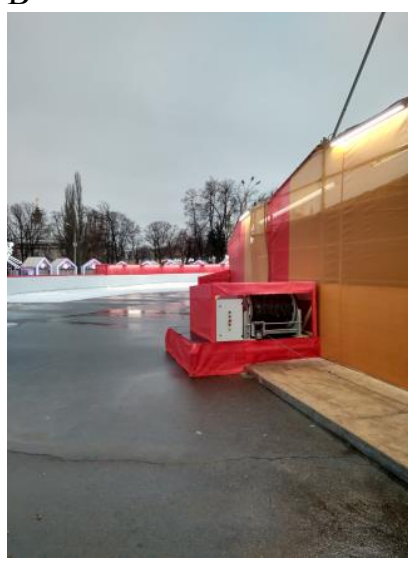

$\mathrm{C}$

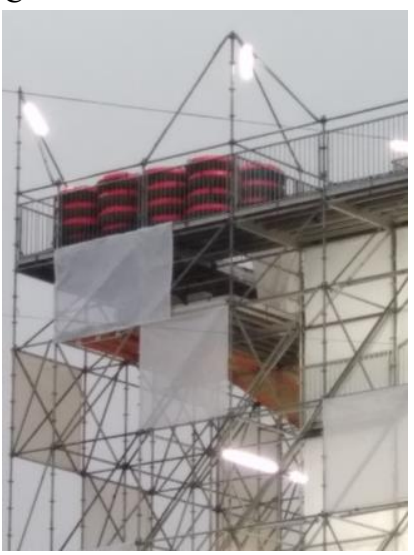

Fig. 5. Organization of tubs lifting, where: A- Ramp of the "Small" slope, B - Lower winch of the "Big" slope. C- Stockpiled tubes on the upper launch pad (photo by author 02.2018).

To organize the stable operation of the slide and the lack of dependence on the weather, it was decided to use the all-season Russian-made coating Snow Plast 365 approaching the quality of natural snow (Fig. 6A). Its basis is a naturally compatible solid-molded polymer module with external dimensions of the standard element $-16.5 \mathrm{~cm} \mathrm{x} 33 \mathrm{~cm}$. (Fig. $6 \mathrm{~B}, \mathrm{C}$ ). Each module has fully molded mounting latches. As a result, it is possible to model sites of any configuration at a time or in several stages, to replace individual elements that have become unusable without destroying the entire coating disk. A white coating was used on the slide for greater association with the snow cover, although it is produced in other colors. The coating went beyond the boundaries of the tracks and was laid as a turning area in the breaking zone.
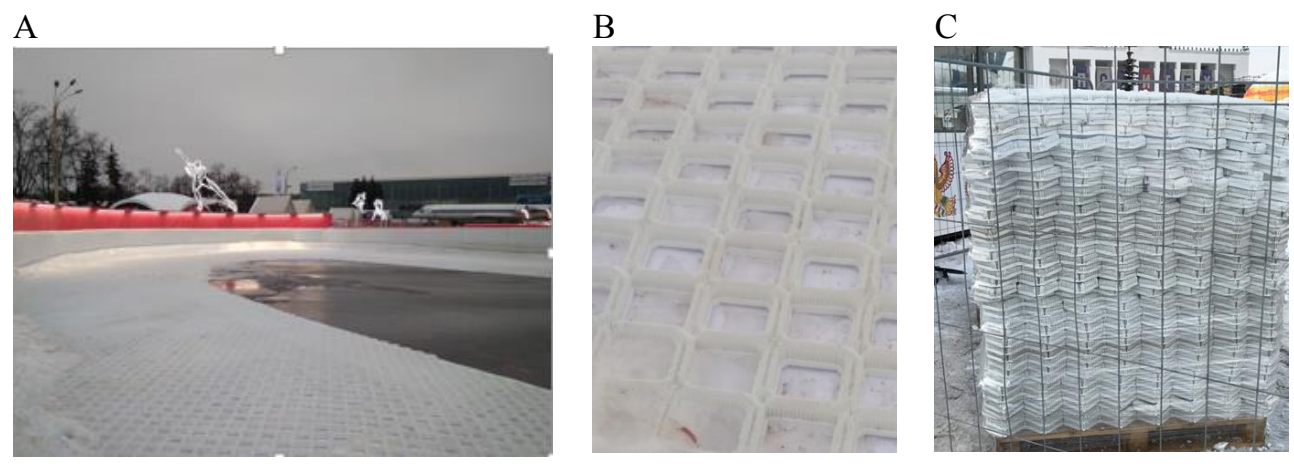

Fig. 6. Coating system of the "Rocket" tubing slide with snow substitute Snow plast 365, where: A Breaking zone. B - Fragment of the coating. C - Stored modules (photo by author 02.2018).

The use of modern engineering systems at snow tubing facilities allows for their efficient and safe operation. Communications must be made for each track - electricity and running water, in some cases, fire hydrants are used to supply water to create ice cover. 
A

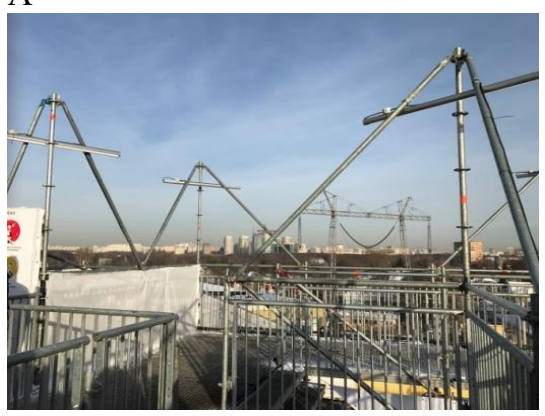

B

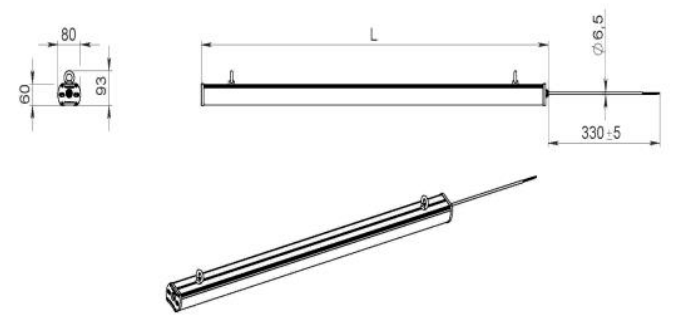

Fig. 7. Lighting system of the "Rocket" slide. A - lamps in the technological state on the cable suspensions (photo by author 02.2018), B - DSO 01-65-50D lamp, size 80x1500x60.

To illuminate the "Rocket" facility and create a decorative effect, more than 600 Nichia (Japan) lighting fixtures were installed, each weighing $2.7 \mathrm{~kg}$, which worked smoothly for two months 24 hours a day. Lamps on the cable suspensions (Fig. 7A) allowed creating a bright and festive atmosphere at the amusement ride and an amazing effect of "floating" and lightness of the structure. The main advantages of the devices (Fig. 7B) are durability and efficiency (about $65 \mathrm{~kW}$ ) and, as a consequence, the overall energy efficiency of the facility.

\subsection{Social role}

As a result of the monitoring of the operation of the "Rocket" slide in the winter season 2017/2018. (Fig. 8), it should be noted that the highest attendance of the object was observed on holidays, which is understandable - this type of activity usually takes from 2 to 4 hours. At the same time, all age groups, especially children and parents (more than $90 \%$ of all visitors), were engaged in active recreation. In the evening, the number of visitors increased and the age structure changed: family users to a youth audience. The "Big" slope, which is more downhill, was of an increased demand. The assumption that only young people go for a ride has not been confirmed. The greatest demand for riding came on families, while the older generation also turned out to be active users.

The number of visitors to the object of more than 150 thousand people shows a high demand for the population of the metropolis in outdoor activities, preferably in known and well-equipped places. Placing new temporary facilities in urban public areas allows diversifying the space and attracting visitors, restoring the traditional activities of adults and children. 
A

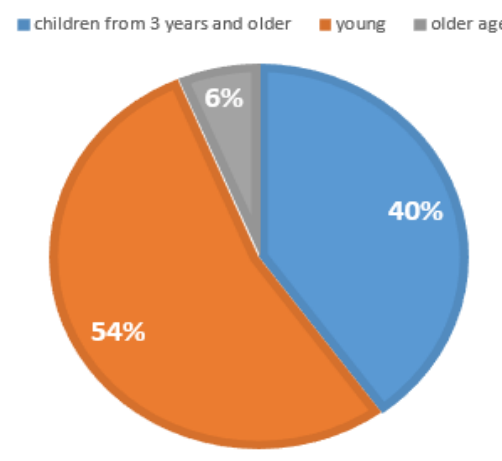

$\mathrm{C}$

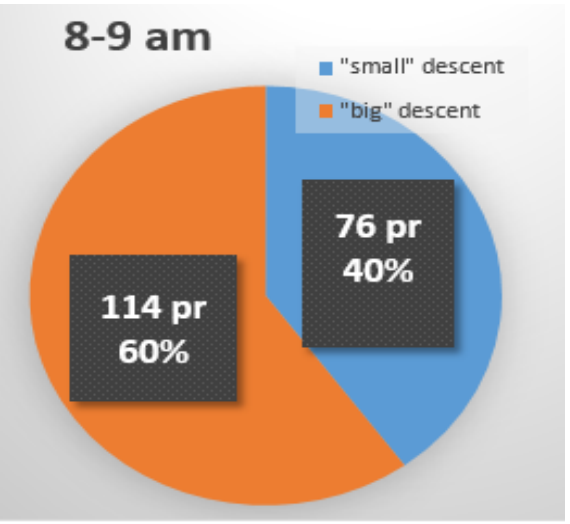

B

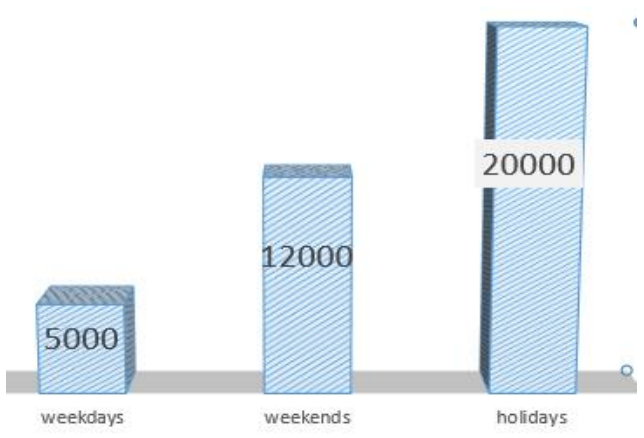

$\mathrm{D}$

\section{0-21 pm}

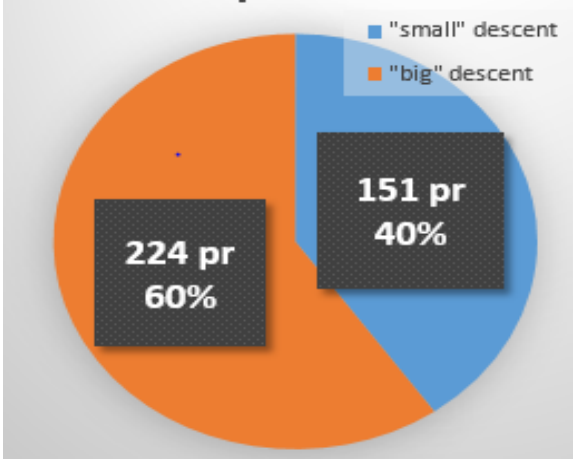

Fig. 8. The attendance statistics of the "Rocket" tubing slides at the VDNH/VVC in 2017-2018, where: A - age groups, B - maximum number of visits per day, C -number and structure of visits in the morning (weekday), D - number and structure of visits in the evening (weekday).

\section{4 "Vsepogorka" slide}

The large-scale recreational tubing facility is located in the Sokolniki recreation park in Moscow and has the longest history. In the current 2018/2019 years, this is the eighth season within the boundaries of the 3rd Radial lane (Fig. 9A). It is the internal motor road of the park. The location of the structure is dictated by the special status of the territory (specially protected natural area) in which the construction of new objects is prohibited, therefore an internal motor road was chosen for the location.

During these years, the structure slightly changed its size, was completed in different ways: in the first years, it had an electric elevator to deliver tubs and visitors to the upper point (for several years, it was absent in order to save). Since the last (seventh) season, travolators have been installed to move visitors and tubs, the movement speed of which is $0.7 \mathrm{~m} / \mathrm{s}$. Riding was available for visitors from the age of 3 years. Visitor statistics depended on weather conditions, calendar day, and time of a day. 
A

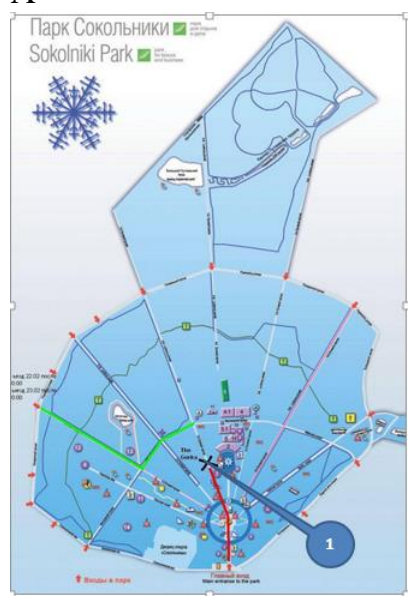

B

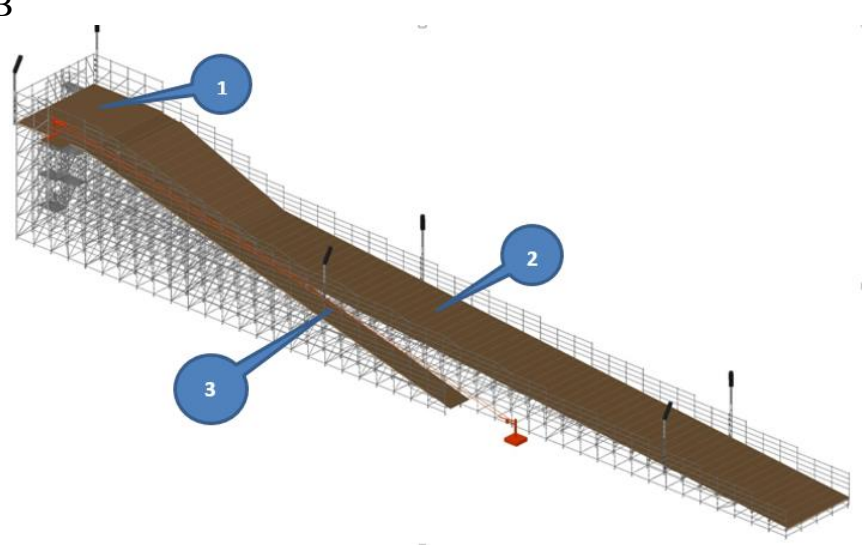

Fig. 9. "Vsepogorka" tubing slide (formerly "The Gorka") Sokolniki, Moscow, where: A - Location within the park. B - Construction scheme: 1-landing zone, 2 - slope, 3 - rise [5].

At present, the length of the slope is $200 \mathrm{~m}$, the height is more than $12 \mathrm{~m}$. The framework of the structure is also made of the COMBI metric wedge scaffolding from the manufacturer company MJ-Gerüst. The rod system includes steel vertical elements, bolts, diagonals, jacks (Fig.9B). Bakelite plywood, wooden beam and fasteners were used as additional materials. The total weight of the structure is 60 tons. (fig.10A) [26, 28]

A

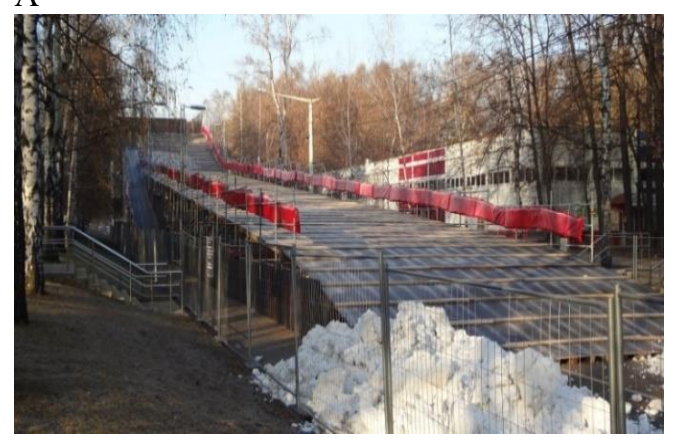

B

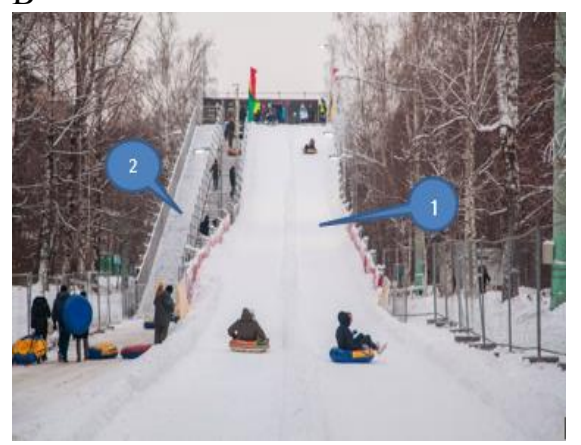

Fig. 10. "Vsepogorka" tubing slide (formerly "The Gorka"), Sokolniki Park, Moscow. A - during the construction season 2015/2016. B - riding season 2017/2018 (1- descent, 2-rise) (photos by author).

Since $2017 / 2018$, the facility has been transformed from a temporary to an all-season one, even the new name "Vseopogorka" speaks about itself. For this, an all-season coating was used as a snow substitute cover. The object is functionally divided into zones: the drop zone - 1, the slope (the upper part is steeper and gently sloping) - 2, and the rise - 3 (Fig. $10 \mathrm{~B})$. In the summer, there are two tracks. The number of visitors is regulated by time; tickets are sold for sessions (as in the pool). 
Table 3. Comparison of parameters of Moscow tubing structures (for the season of 2017/2018).

\begin{tabular}{|c|c|c|c|c|c|c|}
\hline Name & $\begin{array}{c}\text { Structure } \\
\text { type }\end{array}$ & $\begin{array}{c}\text { Size } \\
\mathrm{H} / \mathrm{L}(\mathrm{m})\end{array}$ & $\begin{array}{l}\text { Season of } \\
\text { the use }\end{array}$ & $\begin{array}{c}\text { Lifting } \\
\text { methods } \\
\text { people/tubes }\end{array}$ & $\begin{array}{c}\text { Lifting of } \\
\text { people/tubes }\end{array}$ & $\begin{array}{c}\text { Note } \\
\text { (snow } \\
\text { substitute } \\
\text { manufacturer) }\end{array}$ \\
\hline $\begin{array}{l}\text { "Rocket" } \\
\text { (VDNH) }\end{array}$ & \multirow{2}{*}{ 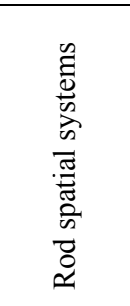 } & $\begin{array}{l}\text { B20/200 } \\
\text { M12/120 }\end{array}$ & $\begin{array}{c}\text { Temporary } \\
\text { winter }\end{array}$ & $\begin{array}{c}\text { walking } \backslash \\
\text { surface lift }\end{array}$ & $\begin{array}{c}\text { walking } \backslash \\
\text { surface lift }\end{array}$ & $\begin{array}{c}\text { Snow plast } \\
365 \text { (Russia) } \\
\text { Necessity - } \\
1100 \mathrm{~m}^{2} \\
\end{array}$ \\
\hline $\begin{array}{l}\text { "Vsepogorka" } \\
\text { (Sokolniki } \\
\text { Park) }\end{array}$ & & $13,5 / 200$ & All-season & $\begin{array}{c}\text { walking } \backslash \\
\text { surface lift }\end{array}$ & $\begin{array}{l}\text { walking/ on } \\
\text { their own }\end{array}$ & $\begin{array}{l}\text { Great Britain, } \\
\text { Necessity - } \\
800 \mathrm{~m}^{2}\end{array}$ \\
\hline
\end{tabular}

\section{Results}

Summarizing the analysis of parameters and characteristics of large Moscow temporary structures (Table 1,3), we note that in Russia, the available historical experience and developments of recent years confirm the possibility of building and using independent constructions from various structures for cultural, sports and recreational activities. The scale, the size and "life cycle" of the created structures may vary depending on the system of factors, including the social orientation of the facilities.

The results of our study show that the construction of a temporary recreational sports facility uses the following sequence of works:

1) installation of metal collapsible structures;

2) fasteners to the frame of wooden flooring and enclosing sides;

3) laying all-season coverage;

4) decoration.

An important aspect of the creation and operation of these facilities is the location, including spatial and functional ability to be installed into the urbanized territory. Architectural and artistic completeness of tubing facilities should be taken into account at the design stage and acceptance for implementation, taking into account the opinions of the population (surveys) [22]. There is practically no doubt about the positive environmental effect of such facilities, which is formed as a result of the formation of infrastructure elements mainly from environmentally friendly structures and materials (collapsible elements, reuse of structural parts, wooden and easily recyclable components). This is facilitated by the purposeful organization of special recreation areas in which the preservation of natural systems (green spaces, natural objects of the territory) is ensured without the spontaneous anthropogenic influence on them.

\section{Discussions}

The study showed that temporary recreational and sports facilities of the winter season in their operation solve an important socio-economic task - maintaining the labor potential of the population through the possibilities of active motor recreation and recuperation. Facilities use fewer resources than permanent ones (for example, snow tubing tracks in specialized parks), are energy efficient, quickly built, require minimal labor, are environmentally friendly, and are accessible to a wide target audience.

The parameters of the city-forming function of temporary recreational facilities as promising centers of urban parks of large cities were analyzed. At the same time, one of the 
main goals is the creation of facilities that significantly increase the quality and efficiency of an entertaining, healthful, and educational pastime (Table 4) of urban residents.

Temporary facilities for recreation and sports are actively responding to new, rapidly evolving requests, including the emergence of functionally new types of leisure.

Table 4. Matrix assessing the adaptability of tubing facilities to the environment.

\begin{tabular}{|c|c|c|c|}
\hline \multicolumn{2}{|r|}{ Parameters } & Large structure & Local facility \\
\hline \multirow[t]{3}{*}{ 1. Relief } & 1.1. Natural (planar object) & + & + \\
\hline & 1.2. Natural + structure & + & \\
\hline & 1.3. Artificial & + & \\
\hline \multirow[t]{2}{*}{ 2. Structure } & 2.1. Rod systems (scaffolding) & + & \\
\hline & 2.2. Wooden frame & & + \\
\hline \multirow{2}{*}{ 3. Coating } & 3.1. Natural (snow, ice) & + & + \\
\hline & 3.2. Artificial & + & \\
\hline \multirow{2}{*}{$\begin{array}{l}\text { 4. Using } \\
\text { scheme }\end{array}$} & 4.1. Temporary seasonal & + & + \\
\hline & 4.2. All-season & + & \\
\hline \multirow[t]{4}{*}{ 5. Location } & 5.1. Parks & + & \\
\hline & 5.2. Public spaces & + & \\
\hline & 5.3. Recreation areas & + & \\
\hline & 5.4. City, district, yard areas & & + \\
\hline \multirow{2}{*}{$\begin{array}{l}\text { 6. Additional } \\
\text { equipment }\end{array}$} & 6.1. Yes & + & \\
\hline & 6.2. No & & + \\
\hline
\end{tabular}

The constructive scheme based on rod building structures and engineering and technological support is studied. The attendance statistics was studied, and the target audience was identified. The constructive and technological aspect of the development of temporary structures serving this area is no less important today. For example, there is a decrease in mass, acceleration and simplification of installation and dismantling of facilities, which allows them to be erected by the forces of consumers without the participation of specialists. Temporary recreational facilities provide an improvement in the work of the entire urban organism as a whole, are biopositive and serve as points of attraction for the population and attract private capital for the improvement of public places. Derogation from typical compositions and giving preference to author's temporary structures helps to attract citizens, and, consequently, to increase the aesthetic and cityplanning parameters of the urban environment in the near future.

On this basis, it should be concluded that the architecture of temporary recreation facilities (seasonal or all-season) is an extremely flexible and environmentally friendly tool that functions successfully and meets the needs of society.

\section{Conclusions}

The use on the territory of cities of temporary socially oriented recreational facilities having historical and cultural traditions is a promising direction. For the last two years, 45 winter tubing tracks were registered in Moscow and the region, many facilities are not registered, as they are created by enthusiasts only for one season.

The relief that was modified in accordance with the requirements of the vertical layout and has already become natural without a significant difference in height makes it necessary to create artificial structures of various architectural forms that diversify the space. The use of heterogeneous constructive and technology solutions to create temporary recreational facilities allows the construction of structures of different "life cycle" with minimal impact on the environment. 


\section{References}

1. Bhawana Singh, U.V. Kiran, Journal Of Humanities And Social Science (IOSR-JHSS) 19(4), 24-30 (2014)

2. R. Sun, Z. Xu, L. Chen, F. Li, Acta Ecologica Sinica 32(7), 1979-1986 (2012) https://doi.org/10.5846/stxb201109131336

3. Y. Zhang, L. Feng, International Journal of Computer Science 9(6), 317-321 (2012)

4. R.G. Prins, S.M. Mohnen, et.al. International Journal of Behavioral Nutrition and Physical Activity 9 (2012) https://doi.org/10.1186/1479-5868-9-90

5. G.S. Cross, Encyclopedia of recreation and leisure in America. The Scribner American civilization series (Charles Scribner's Sons, Farmington Hills, MI, 2004)

6. R. Hansmann, S.M. Hug, K. Seeland, Urban forestry \& urban greening, Elsevier 6(4), 213-225 (2007)

7. N.M. Vetrova, Environmental safety recreational region, monograph (RIO NAPCS, Simferopol, 2006)

8. P.V. Panchenko, Bulletin. state architectural.-builds. Univ. Ser.: Construction and architectural 23(42), 156-161 (2011)

9. A. Bochaver, A. Korzun, K. Polivanova, SSRN (2017) https://doi.org/10.2139/ssrn.2928013

10. R. Forrest, A. Kearns, Urban Studies 38(12), 2125-2143 (2001) https://doi.org/10.1080/00420980120087081

11. N. Baron-Yelles, S.A. Clavé, Loisir et Societe 37(1), 18-37 (2014) https://doi.org/10.1080/07053436.2014.881090

12. C. Chen, L.T. Tsai, C.F. Lin, C.C. Huang, Y.T. Chang, R.Y. Chen, S.Y. Lyu, PLoS ONE 12(5) (2017) https://doi.org/10.1371/journal.pone.0178052

13. B.W. Ahn, T.J. Chon, Supplement 15(2), 1331-1339 (2018)

14. Z. Hong, Int. symp. - common development of sports and modern society 1, 244-250 (2013)

15. M. Afonina, A. Marshalkovich, 8th International Conference «Science and Technology» by SCIEURO in London 1(2), 50-63 (2017)

16. M. Afonina, E. Shcherbina, A Balakina, SPC 7(2.13), 210-219 (2018) DOI: 10.14419/ijet.v7i2.13.11689

17. Z. Ivanova, M. Afonina, Procedia Engineering 165, 1402-1409 (2016) www.iencedirect.com/science/article/pii/S18777058163

18. M.I. Afonina, E. Shcherbina, J. Biosphere compatibility: people, region, technology 2(14), 29-37 (2016)

19. E. Shcherbina, M. Afonina, MATEC 86, $03012 \quad$ (2016) http://dx.doi.org/10.1051/matecconf/20168603012

20. A. Aleshin, M. Afonina Internet-vestnik VolgGASU 2014, 4(35) (2014)

21. M.I. Afonina, M. Pairavand, Vestnik of Tomsk state university of architecture and building 3, 61-69 (2016)

22. M. Afonina, O.L. Knyazeva, Scientific and Technical Journal on Constraction and Architecture 8(60), 147-155 (2017)

23. M.I. Afonina, M. Pairavand, E.S. Sokolova, Ecology of urbanized areas 3, 79-83 (2015

24. M.I. Afonina, M.I. Gandzhutzev, Ecology of urbanized areas 1, 65-69 (2018) 